\title{
The Effect of Hydrogen on the Growth of Desulfovibrio vulgaris (Hildenborough) on Lactate
}

\author{
By I. P. PANKHANIA, $\dagger$ L. A. GOW AND W. A. HAMILTON* \\ Department of Microbiology, Marischal College, University of Aberdeen, \\ Aberdeen AB9 IAS, UK
}

(Received 28 April 1986; revised 2 July 1986)

\begin{abstract}
Desulfotibrio vulgaris (Hildenborough) was grown on lactate with either a $\mathrm{N}_{2} / \mathrm{CO}_{2}$ or a $\mathrm{H}_{2} / \mathrm{CO}_{2}$ gas phase. $\mathrm{H}_{2}$ increased the growth yield on lactate and had a sparing effect on lactate utilization, without altering the growth rate or hydrogenase level. Growth on acetate plus $\mathrm{CO}_{2}$ with $\mathrm{H}_{2}$ as sole energy source did not require an extensive adaptation period. Addition of lactate to cultures growing on acetate and $\mathrm{H}_{2} / \mathrm{CO}_{2}$ resulted in a switch from acetate to lactate utilization. In lactate-limited medium under $\mathrm{H}_{2} / \mathrm{CO}_{2}$ biphasic growth was observed. Lactate was oxidized first with production of acetate, followed by a second phase of growth on the acetate. Under this condition $\mathrm{H}_{2}$ did not provide any supplementary energy during growth on lactate, as was evident from the ratio of lactate utilized to acetate produced.
\end{abstract}

\section{INTRODUCTION}

Sulphate-reducing bacteria (SRB) constitute an integral part of mixed microbial populations or consortia in sulphate-containing environments (Pfenning \& Widdel, 1982; Hamilton, 1985). Their diverse metabolic capabilities (Peck \& LeGall, 1982; Odom \& Peck, 1984) allow them to carry out various interactions in different ecological niches such as marine and estuarine sediments, and biofilms. SRB are capable of growth on a wider range of substrates than had been previously appreciated (Pfennig et al., 1981), and are thus very flexible ecologically. The relative importance of various intermediates of the mineralization process for the growth of SRB has recently been receiving increased attention (Jørgensen, 1982). Acetate in particular has been shown to be an important substrate for sulphate reduction, accounting for between $50 \%$ and $65 \%$ of the electron donors in marine environments (Sørensen et al., 1981; Christensen, 1984). Many SRB capable of growth on acetate as sole source of carbon and energy with sulphate as terminal electron acceptor have been isolated by F. Widdel (Pfennig et al., 1981).

Desulfovibrio vulgaris, on the other hand, is only able to grow on organic compounds such as lactate, oxidizing them incompletely to acetate. Badziong et al. (1978), however, isolated a Desulfovibrio species which utilized $\mathrm{H}_{2}$ as the sole energy source and acetate and $\mathrm{CO}_{2}$ as carbon sources. Approximately $70 \%$ of the cell carbon was derived from acetate and $30 \%$ from $\mathrm{CO}_{2}$. It was believed at the time that this organism differed from the type strain $D$. vulgaris (Hildenborough) in this capacity to grow on $\mathrm{H}_{2}$ in a minimal medium with acetate and $\mathrm{CO}_{2}$. However, Brandis \& Thauer (1981) were able to adapt D. vulgaris (Hildenborough) and other Desulfovibrio spp. to grow on $\mathrm{H}_{2}$ as energy source.

$\mathrm{H}_{2}$ is now believed to play a central role in the metabolism of Desulfovibrio, although the physiological function of $\mathrm{H}_{2}$ and hydrogenase in the growth of SRB remains the subject of much discussion (Odom \& Peck, 1984). Many Desulfovibrio spp. have the unique ability not only to oxidize $\mathrm{H}_{2}$ (Brandis \& Thauer, 1981; Nethe-Jaenchen \& Thauer, 1984) but also to produce it,

† Present address: Philipps-Universität, FB Biologie, D-3550 Marburg, FRG.

Abbreviation: SRB, sulphate-reducing bacteria. 
even in the presence of sulphate (Tsuji \& Yagi, 1980; Traore et al., 1981). The possible physiological significance of this phenomenon has been discussed by several workers (Hatchikian et al., 1976; Tsuji \& Yagi, 1980; Odom \& Peck, 1981, 1984; Lupton et al., 1984). One hypothesis is the obligate $\mathrm{H}_{2}$-cycling mechanism linked to chemiosmotic energy metabolism (Odom \& Peck, 1981). Electrons from lactate oxidation are transferred to protons, producing $\mathrm{H}_{2}$ by the cytoplasmic hydrogenase. This $\mathrm{H}_{2}$ then diffuses across the cell membrane where it is oxidized by the periplasmic hydrogenase, creating a proton gradient across the membrane and thus allowing energy transduction. Another model by Lupton et al. (1984) envisages the production of internal $\mathrm{H}_{2}$ by cytoplasmic hydrogenase as regulating the redox state of electron carriers and so preventing the loss of energy by oxidizing $\mathrm{H}_{2}$ in the periplasm.

In the investigation described here, the effect of $\mathrm{H}_{2}$ on growth, lactate oxidation and hydrogenase levels in $D$. vulgaris was studied. The capability of $\mathrm{H}_{2}$ /acetate-grown cultures to utilize lactate was also investigated.

\section{METHODS}

Organism and media. D. vulgaris (Hildenborough) NCIB 8303 was obtained from the National Collections of Industrial and Marine Bacteria Ltd, Aberdeen, UK. The bacteria were maintained in a medium containing ( $\mathrm{g}$ $\left.1^{-1}\right): \mathrm{Na}_{2} \mathrm{SO}_{4}, 3 \cdot 0 ; \mathrm{KH}_{2} \mathrm{PO}_{4}, 0.2 ; \mathrm{NH}_{4} \mathrm{Cl}, 0.25 ; \mathrm{NaCl}, 1.0 ; \mathrm{MgCl}_{2} .6 \mathrm{H}_{2} \mathrm{O}, 0.4 ; \mathrm{KCl}, 0.5 ; \mathrm{CaCl}_{2} .2 \mathrm{H}_{2} \mathrm{O}, 0.15 ;$ resazurin, 0.001 ; sodium lactate $(70 \% \mathrm{w} / \mathrm{w}), 5 \mathrm{ml}$. The medium was boiled, cooled under $\mathrm{O}_{2}$-free $\mathrm{N}_{2}$ and $50 \mathrm{ml}$ volumes were dispensed into $100 \mathrm{ml}$ Wheaton bottles (Supelco).

The bottles were stoppered with black butyl rubber stoppers and clamped with aluminium caps (Bellco). A solution of $\mathrm{Na}_{2} \mathrm{~S} .9 \mathrm{H}_{2} \mathrm{O}(1 \%, \mathrm{w} / \mathrm{v})$ was injected into each bottle to give a final concentration of $0.01 \mathrm{~g} \mathrm{l}^{-1}$. The culture bottles were pressurized to 0.5 bar with $\mathrm{N}_{2}$ and autoclaved for $20 \mathrm{~min}$ at $121^{\circ} \mathrm{C}$. After autoclaving, $1 \mathrm{ml} l^{-1}$ sterile anoxic trace element solution (Widdel, 1980 ) was added and the $\mathrm{pH}$ adjusted to 6.8 with $0.3 \mathrm{ml} 8.4 \%(\mathrm{w} / \mathrm{v})$ $\mathrm{NaHCO}_{3}$. The medium was inoculated with a $2 \%(\mathrm{v} / \mathrm{v})$ inoculum and incubated at $35^{\circ} \mathrm{C}$. The culture was transferred into fresh medium every second day.

The growth medium contained the following $\left(\mathrm{g} \mathrm{I}^{-1}\right):\left(\mathrm{NH}_{4}\right)_{2} \mathrm{SO}_{4}, 6 \cdot 6 ; \mathrm{NaCl}, 1 \cdot 8 ; \mathrm{KH}_{2} \mathrm{PO}_{4}, 0 \cdot 9 ; \mathrm{MgCl}_{2} .6 \mathrm{H}_{2} \mathrm{O}$, $0.36 ; \mathrm{CaCl}_{2} .2 \mathrm{H}_{2} \mathrm{O}, 0.26$; resazurin, 0.001 ; sodium lactate $(70 \%, \mathrm{w} / \mathrm{w}), 5 \mathrm{ml}$ or sodium acetate, $2.5 ;$ trace mineral solution (Brandis \& Thauer, 1981), $12.5 \mathrm{ml}$. The trace mineral solution was autoclaved separately and the $\mathrm{pH}$ of the medium adjusted to 6.8 with sterile $10 \%(\mathrm{w} / \mathrm{v}) \mathrm{Na}_{2} \mathrm{CO}_{3}$.

pH-stat batch culture. The apparatus is shown in Fig. 1. Each vessel was autoclaved aerobically and then connected up with butyl rubber tubing (Esco Rubbers). The gas mixture (I) $\left(80: 20, \mathrm{v} / \mathrm{v}, \mathrm{N}_{2} / \mathrm{CO}_{2}\right.$ or $\mathrm{H}_{2} / \mathrm{CO}_{2}$ ) was passed over copper turnings which were heated at $350{ }^{\circ} \mathrm{C}$ to remove traces of $\mathrm{O}_{2}$ and through a 11 bottle (II) containing sterile distilled water and resazurin $\left(0.001 \mathrm{~g} \mathrm{l}^{-1}\right)$. It was then bubbled through a 51 bottle (III) containing sterile medium before entering the culture vessel (IV), which contained $400 \mathrm{ml}$ growth medium. After equilibration with $\mathrm{N}_{2} / \mathrm{CO}_{2}$ or $\mathrm{H}_{2} / \mathrm{CO}_{2}$ (flow rate $\left.250 \mathrm{ml} \mathrm{min}^{-1}\right), 10 \mathrm{ml} \% \%(\mathrm{w} / \mathrm{v}) \mathrm{Na}_{2} \mathrm{~S} .9 \mathrm{H}_{2} \mathrm{O}$ was added to the 11 bottle (II) and within $20 \mathrm{~min}$ the medium was reduced as evidenced by the disappearance of the blue colouration of the resazurin. The $\mathrm{pH}$ in the culture vessel was maintained at 6.8 by the automatic addition of $10 \%(\mathrm{v} / \mathrm{v}) \mathrm{H}_{2} \mathrm{SO}_{4}$ using a $\mathrm{pH}$ controller (LH Engineering). A butyl rubber tubing connection was made between the bottle containing acid and the culture vessel (IV) so as to compensate for the negative pressure that would be formed due to the automatic removal of acid from the bottle. The samples for the measurement of growth, substrate utilization and product formation were withdrawn from the culture vessel using the sampling port (V).

Growth was followed by measuring optical density at $578 \mathrm{~nm}$ in a Pye-Unicam SP305 spectrophotometer after diluting the sample $1: 1$ with $1 \mathrm{M}$-maleinate $/ \mathrm{NaOH}$ buffer $\mathrm{pH} 6.5$ and adding a few granules of sodium dithionite. For dry weight measurements $20 \mathrm{ml}$ culture was withdrawn and immediately filtered through a $0.45 \mu \mathrm{m}$ membrane filter (Millipore) and washed twice with $20 \mathrm{ml} 1 \%(\mathrm{w} / \mathrm{v}) \mathrm{NaCl}$. The filters were dried at $90^{\circ} \mathrm{C}$ overnight in an oven. Appropriate corrections were made for the blank prepared by filtering uninoculated growth medium and washing with $\mathrm{NaCl}$.

Hydrogenase. The enzyme was assayed as $\mathrm{H}_{2}$-consuming activity by following spectrophotometrically the reduction of methyl viologen at $578 \mathrm{~nm}$ (Pankhania et al., 1986a), and as $\mathrm{H}_{2}$-producing activity by an electrochemical method using a $\mathrm{H}_{2}$ electrode (Hansatech) (Gow et al., 1986). Hydrogenase activity was sensitive to inactivation by $\mathrm{O}_{2}$ if the cells were grown under $\mathrm{H}_{2} / \mathrm{CO}_{2}$, whereas under $\mathrm{N}_{2} / \mathrm{CO}_{2}$ the enzyme was extremely stable (I. P. Pankhania, unpublished results). For this reason the cells grown under a $\mathrm{H}_{2} / \mathrm{CO}_{2}$ gas phase were collected anaerobically (Pankhania et al., 1986 b). Cultures were centrifuged at $10000 \mathrm{~g}$ for $20 \mathrm{~min}$ and the pellets were resuspended in $50 \mathrm{~mm}-\mathrm{Tris} / \mathrm{HCl}$ buffer, $\mathrm{pH} 7.5$, containing $50 \mathrm{mM}-\mathrm{NaCl}$ and $1 \mathrm{~mm}$-dithiothreitol. Cells were broken by passage through a French pressure cell, centrifuged at $10000 \mathrm{~g}$ for $20 \mathrm{~min}$, and the supernatants were examined for the hydrogenase activities in the absence or presence of $\mathrm{CO}$ as described by Gow et al. (1986). 


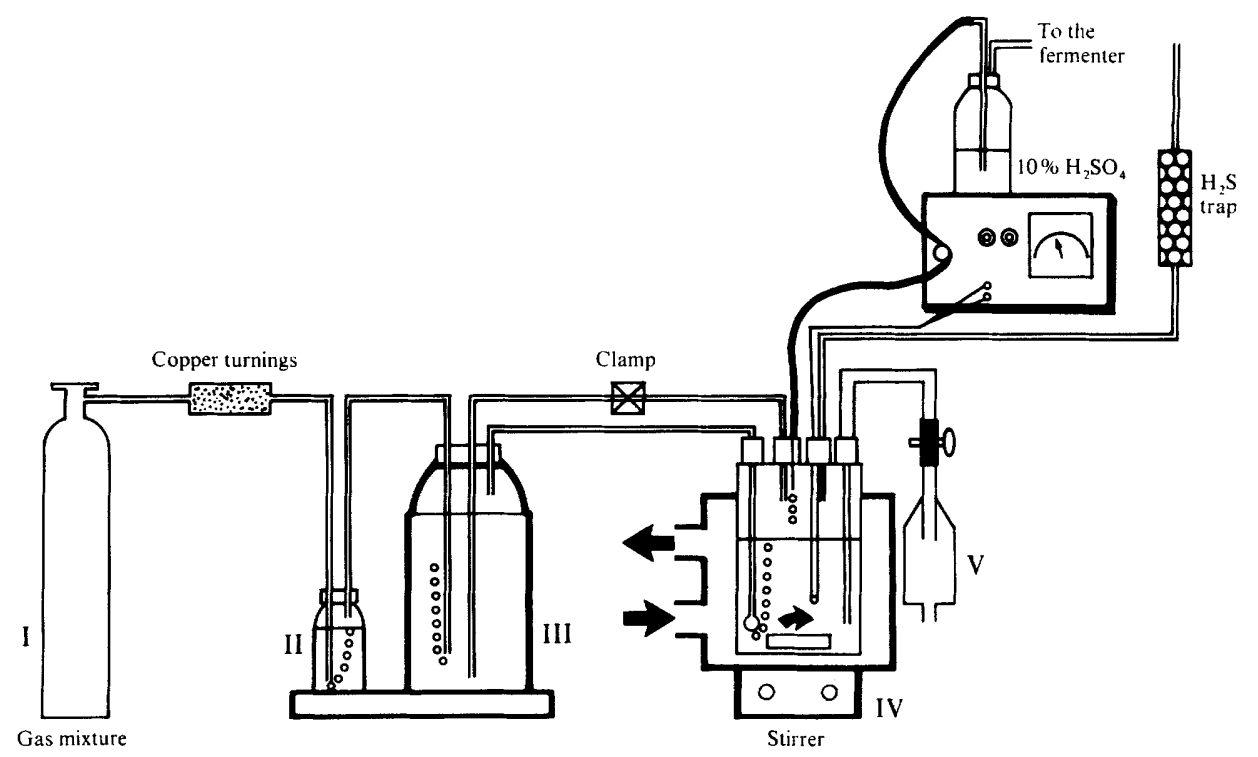

Fig. 1. Diagram of the $\mathrm{pH}$-stat batch culture apparatus. I, Gas cylinder: 11,11 bottle containing $750 \mathrm{ml}$ distilled water and $0.001 \mathrm{~g}$ resazurin $\mathrm{l}^{-1}$; III, 51 medium reservoir bottle; IV, $500 \mathrm{ml}$ fermenter with a water jacket; V, sampling port.

Measurement of sulphate, lactate and acetate. Sulphate was assayed turbidimetrically (Taras et al., 1971). Lactate and acetate were measured by gas chromatography (Pye-Unicam PU4500) on a GP $15 \% \mathrm{SP}-1220 / 1 \% \mathrm{H}_{3} \mathrm{PO}_{4}$ on 100-120 Chromosorb WAW (Supelco) column (1.82 $\mathrm{m} \times 4 \mathrm{~mm}$ i.d.) with a flame ionization detector. The carrier

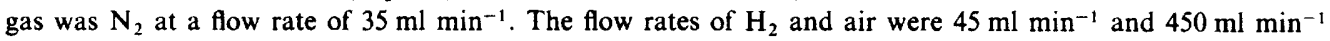
respectively. The temperatures of the detector and injector were $170^{\circ} \mathrm{C}$ and that of the column was $115^{\circ} \mathrm{C}$. Culture $(5 \mathrm{ml})$ was centrifuged at $13000 \mathrm{~g}$ in a Micro Centaur (MSE) centrifuge for $10 \mathrm{~min}$ and the supernatant was used for the analyses. For acetate, $500 \mu \mathrm{l}$ supernatant was acidified with $50 \mu$ l concentrated $\mathrm{HCl}$ and a $2 \mu \mathrm{l}$ sample was injected in the chromatograph. Lactate was first methylated as described in the Supplement to Supelco Bulletin $748 \mathrm{~F}$ and a $2 \mu 1$ sample was used for analysis. Appropriate standards were run to calculate the concentrations of acetate and lactate in the samples.

\section{RESULTS}

\section{Effect of $\mathrm{H}_{2}$ on growth on lactate}

Growth of SRB is generally poor in closed bottles because of the toxic effects of the $\mathrm{H}_{2} \mathrm{~S}$ produced (Postgate, 1984; Klemps et al., 1985). Additionally, even if the medium is well chelated the accumulation of sulphide can cause precipitation of iron, which makes it difficult to measure growth by following the increase in optical density. A further problem in our experiments was that during growth of $D$. vulgaris under $\mathrm{N}_{2} / \mathrm{CO}_{2}$ the $\mathrm{pH}$ shifted from 6.8 to 7.2 , whereas under $\mathrm{H}_{2} / \mathrm{CO}_{2}$ the increase was up to $\mathrm{pH} 7 \cdot 8$, which resulted in lysis of the cells (data not shown). Therefore, the batch culture with a $\mathrm{pH}$ controller was set up in which at the constant $\mathrm{pH}$ of 6.8, sulphide was removed from the culture as $\mathrm{H}_{2} \mathrm{~S}$ in the gas stream (Fig. 1).

Growth of $D$. vulgaris on lactate under $\mathrm{N}_{2} / \mathrm{CO}_{2}$ or $\mathrm{H}_{2} / \mathrm{CO}_{2}$ was followed by measuring increase in optical density, lactate utilization, acetate production and hydrogenase activity (data not shown). Growth stopped upon exhaustion of lactate. The periplasmic hydrogenase activity increased with time and followed growth. No increase in the hydrogenase activity was observed when the enzyme was assayed in the presence of Triton X-100. Odom \& Peck (1981) have reported an increase in the enzyme activity in the presence of Triton X-100 which has been thought to be due to the presence of a second cytoplasmic hydrogenase. 


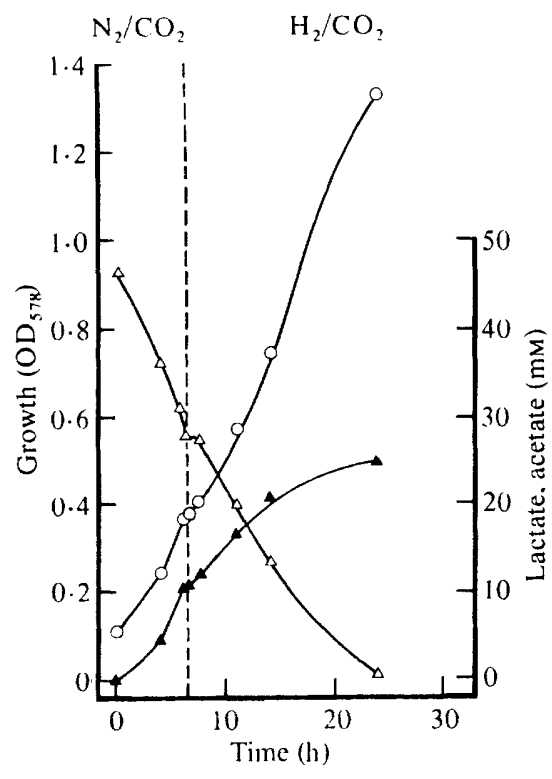

Fig. 2

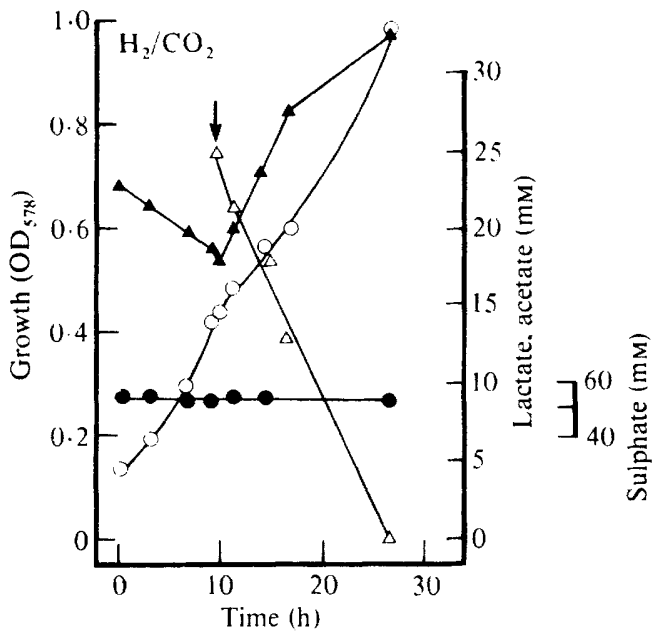

Fig. 3

Fig. 2. Growth (O) of D. vulgaris on lactate under $\mathrm{N}_{2} / \mathrm{CO}_{2}$ followed by $\mathrm{H}_{2} / \mathrm{CO}_{2}$ (the change in gas phase is indicated by the dashed line). Lactate $(\triangle)$ and acetate $(\boldsymbol{\Lambda})$ were measured by gas chromatography as described in Methods.

Fig. 3. Growth $(\mathrm{O})$ of $D$. vulgaris on acetate under $\mathrm{H}_{2} / \mathrm{CO}_{2}$. The arrow indicates the time $(9 \mathrm{~h})$ when 25 $\mathrm{mM}$-lactate was added to the growth vessel. Lactate $(\triangle)$, acetate $(\boldsymbol{\Delta})$ and sulphate $(\boldsymbol{O})$ were measured as described in Methods.

Table 1. Growth parameters of D. vulgaris on lactate under $\mathrm{N}_{2} / \mathrm{CO}_{2}$ or $\mathrm{H}_{2} / \mathrm{CO}_{2}$ gas phases

The results are means of triplicate determinations.

\begin{tabular}{|c|c|c|c|c|c|c|}
\hline \multirow[b]{2}{*}{ Gas phase } & \multirow[b]{2}{*}{$Y\left(\mathrm{~g} \mathrm{l}^{-1}\right)$} & \multirow[b]{2}{*}{$t_{\mathrm{J}}(\mathrm{h})$} & \multirow{2}{*}{$\begin{array}{l}\text { Lactate/ } \\
\text { acetate }\end{array}$} & \multirow{2}{*}{$\begin{array}{c}Y_{\text {lactate }} \\
\text { (g dry wt } \\
\text { cells mol }{ }^{-1} \text { ) }\end{array}$} & \multicolumn{2}{|c|}{ Hydrogenase ${ }^{*}\left[\mathrm{U}(\mathrm{g} \text { dry } w t)^{-1}\right]$} \\
\hline & & & & & $\mathrm{H}_{2}$ production & $\mathrm{H}_{2}$ consumption \\
\hline $\mathrm{N}_{2} / \mathrm{CO}_{2}$ & 0.255 & 3.7 & $1 \cdot 17$ & 5.95 & $10 \cdot 3$ & $7 \cdot 18$ \\
\hline $\mathrm{H}_{2}^{-1} / \mathrm{CO}_{2}$ & 0.43 & $3 \cdot 8$ & $1 \cdot 70$ & 8.75 & $9 \cdot 56$ & $5 \cdot 45$ \\
\hline
\end{tabular}

When the gas phase was changed from $\mathrm{N}_{2} / \mathrm{CO}_{2}$ to $\mathrm{H}_{2} / \mathrm{CO}_{2}$ a short lag of about $1 \mathrm{~h}$ was observed before there were further increases in cell mass (Fig. 2) and hydrogenase activities (data not shown). The growth parameters under $\mathrm{N}_{2} / \mathrm{CO}_{2}$ and $\mathrm{H}_{2} / \mathrm{CO}_{2}$ gas phases are summarized in Table $1 . \mathrm{H}_{2}$ had a pronounced effect on growth of D. vulgaris on lactate. In the presence of $\mathrm{H}_{2}$, there were increases in growth yield and in the ratio of lactate consumed to acetate produced. However, there was no significant effect on the growth rate or the hydrogenase activity, suggesting that the periplasmic hydrogenase may be a constitutive enzyme. Hydrogenase activity was therefore measured in crude extracts of $D$. rulgaris grown with lactate under $\mathrm{N}_{2} / \mathrm{CO}_{2}$ or $\mathrm{H}_{2} / \mathrm{CO}_{2}$, and with acetate under $\mathrm{H}_{2} / \mathrm{CO}_{2}$. The activities were respectively, 5.7, 5.2 and $3.4 \mu \mathrm{mol} \mathrm{H}_{2}$ produced $\min ^{-1}$ (mg protein) $)^{-1}$. When the enzyme was measured in the presence of $\mathrm{CO}$, however, cells grown on lactate under $\mathrm{N}_{2} / \mathrm{CO}_{2}$ retained nearly $18 \%$ of the original activity $\left(1.0 \mu \mathrm{mol} \mathrm{H}_{2} \mathrm{~min}^{-1} \mathrm{mg}^{-1}\right)$. This indicates that under such growth conditions there may be more membrane-bound hydrogenase (Gow et al., 1986). Comparable figures for lactate and acetate under $\mathrm{H}_{2} / \mathrm{CO}_{2}$ were respectively, $3.8 \%\left(0 \cdot 2 \mu \mathrm{mol} \mathrm{H}_{2} \mathrm{~min}^{-1} \mathrm{mg}^{-1}\right)$ and $5.9 \%\left(0 \cdot 2 \mu \mathrm{mol} \mathrm{H}_{2} \mathrm{~min}^{-1} \mathrm{mg}^{-1}\right)$. 


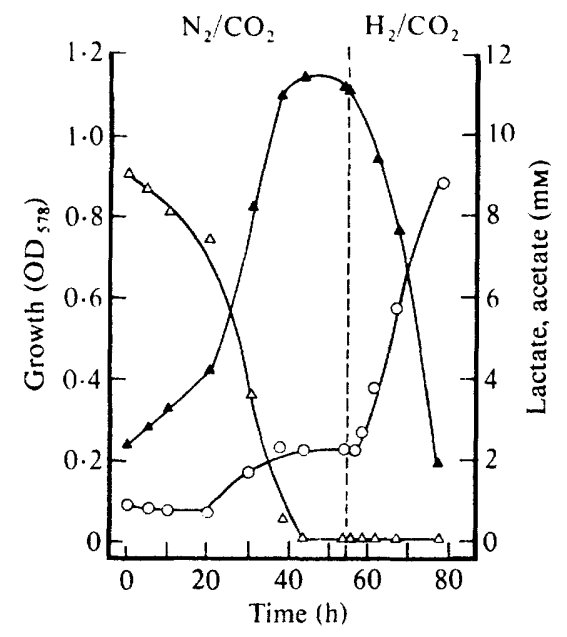

Fig. 4

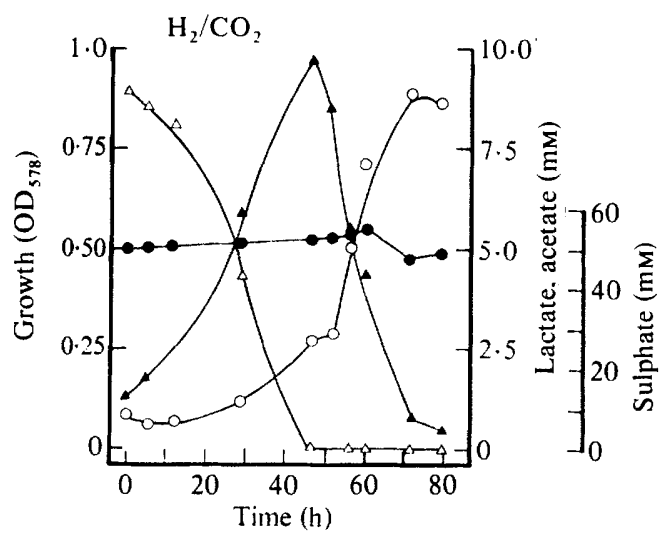

Fig. 5

Fig. 4. Growth $(O)$ of $D$. vulgaris in lactate-limited medium under $\mathrm{N}_{2} / \mathrm{CO}_{2}$. After $54 \mathrm{~h}$ the gas was changed to $\mathrm{H}_{2} / \mathrm{CO}_{2}$ (indicated by the dashed line). Acetate in the growth vessel at zero time was carried over in the inoculum. Lactate $(\triangle)$ and acetate $(\boldsymbol{\Delta})$ were measured as described in Methods.

Fig. 5. Growth $(O)$ of $D$. vulgaris in lactate-limited medium under $\mathrm{H}_{2} / \mathrm{CO}_{2}$. Lactate $(\triangle)$, acetate $(\Delta)$ and sulphate (O) were measured as described in Methods.

\section{Preferential utilization of lactate}

It was not known whether cultures adapted to grow on $\mathrm{H}_{2} / \mathrm{CO}_{2}$ and acetate would utilize lactate. The data presented above show that $D$. vulgaris did not use acetate as a carbon source when growing on lactate with either $\mathrm{N}_{2} / \mathrm{CO}_{2}$ or $\mathrm{H}_{2} / \mathrm{CO}_{2}$ as gas phase. However, the addition of lactate to cultures growing with $\mathrm{H}_{2}$ as energy source resulted in a switch from acetate to lactate utilization, which was evident from the further production of acetate (Fig. 3).

\section{Growth with $\mathrm{H}_{2}$ as the sole energy source}

D. vulgaris (Hildenborough) was originally thought to differ from D. vulgaris strains Marburg and Madison in that it could not be grown with $\mathrm{H}_{2}$ as sole energy source (Badziong et al., 1978). It was later demonstrated that the ability to grow on $\mathrm{H}_{2}$ was common to other species (Brandis \& Thauer, 1981); D. vulgaris (Hildenborough), however, required an elaborate adaptation period prior to growth on $\mathrm{H}_{2}$. In our studies no such adaptation period was required (Pankhania et al., $1986 \mathrm{~b}$ ) although a lag period of about $18 \mathrm{~h}$ was observed when a lactate-grown culture was subcultured into acetate medium under $\mathrm{H}_{2} / \mathrm{CO}_{2}$. After four subcultures growth and acetate utilization were measured (data not shown). The growth rate was similar to that observed with lactate.

\section{Growth of D. vulgaris in lactate-limited medium}

Growth of $D$. vulgaris in medium containing $9 \mathrm{~mm}$-lactate was followed under a gas phase of $\mathrm{N}_{2} / \mathrm{CO}_{2}$. The growth rate was low and growth stopped when lactate was completely utilized (Fig. 4), the acetate produced from lactate not being utilized further. However, when the gas phase was changed to $\mathrm{H}_{2} / \mathrm{CO}_{2}$, growth was much faster, after a lag phase of approximately $2 \mathrm{~h}$. When the above experiment was carried out entirely under $\mathrm{H}_{2} / \mathrm{CO}_{2}$, a biphasic growth pattern was observed, lactate first being oxidized to acetate, followed immediately by growth on acetate after exhaustion of the lactate (Fig. 5). A surprising observation was that the ratio of lactate consumed to acetate formed was nearly 1 rather than 2 as found with excess lactate (Table 1 ). These data suggest that $\mathrm{H}_{2}$ may not serve as an energy source in the presence of limiting lactate. 


\section{DISCUSSION}

One of the aims of this work was to look for evidence for or against the $\mathrm{H}_{2}$-cycling mechanism as proposed by Odom \& Peck (1981). A major problem for this hypothesis is that the standard redox potentials for the two half reactions lactate $\rightarrow$ pyruvate $+2 \mathrm{H}^{+}+2 \mathrm{e}^{-}\left(E_{0}^{\prime}=-197 \mathrm{mv}\right)$ and $2 \mathrm{H}^{+}+2 \mathrm{e}^{-} \rightarrow \mathrm{H}_{2}\left(E_{0}^{\prime}=-420 \mathrm{mV}\right)$ are such that $\mathrm{H}_{2}$ production from the oxidation of lactate is endergonic. Because of the unfavourable position of the equilibrium of the reaction therefore, the oxidation of lactate can only proceed at very low $\mathrm{H}_{2}$ concentrations and/or high lactate : pyruvate ratios. Even with a lactate :pyruvate ratio of $100: 1$, this would require a partial pressure of $\mathrm{H}_{2}$ less than $10^{-5} \mathrm{~atm}$. According to the $\mathrm{H}_{2}$-cycling hypothesis therefore, oxidation and growth on lactate should be inhibited by $\mathrm{H}_{2}$ partial pressures in excess of $10^{-5} \mathrm{~atm}$. Data obtained in this study, however, suggest that $\mathrm{H}_{2}$ did not inhibit lactate oxidation. Instead it had a sparing effect on lactate utilization and increased the growth yield on lactate. Lupton $e t$ al. (1984) also observed no inhibition of growth or substrate consumption when $D$. vulgaris (Madison) was cultured on lactate in the presence of $\mathrm{H}_{2}$. We have additionally shown that $D$. vulgaris grown on lactate in a sulphate- $(10 \mathrm{~mm})$ limited chemostat does not suffer wash-out at low dilution rate under a $\mathrm{H}_{2} / \mathrm{CO}_{2}$ gas phase (I. P. Pankhania, unpublished results). Similar results using sulphate-limited chemostats were obtained by Nethe-Jaenchen \& Thauer (1984) with D. vulgaris (Marburg) and by Cypionka \& Pfennig (1986) with Desulfotomaculum orientis. Other evidence against the $\mathrm{H}_{2}$-cycling hypothesis comes from the lack of inhibition of synthesis or activity of lactate dehydrogenase by $\mathrm{H}_{2}$ (Hamilton, 1982) and the production of $\mathbf{H}_{2}$ during growth on lactate plus sulphate (Tsuji \& Yagi, 1980; Traore et al., 1981). Lupton et al. (1984) have proposed a trace $\mathrm{H}_{2}$ transformation model for the physiological function of $\mathrm{H}_{2}$ metabolism during growth of $D$. vulgaris on organic electron donors. In this model, hydrogenases function in regulating electron flow and preventing energy loss by producing and consuming $\mathrm{H}_{2}$ respectively. An alternative explanation would be that the energetically unfavourable oxidation of lactate is driven by energy-dependent reversed electron transport in line with the model suggested by Thauer \& Morris (1984).

Another requirement for the mechanism of $\mathrm{H}_{2}$-cycling is the presence of two hydrogenases, one in the periplasm, functioning as a $\mathrm{H}_{2}$-consuming hydrogenase, and another in the cytoplasm, functioning as a $\mathrm{H}_{2}$-producing hydrogenase (Odom \& Peck, 1984). Our results suggest that two hydrogenases are present in $D$. vulgaris. The second, membrane-bound hydrogenase can be detected in the presence of $\mathrm{CO}$. The membrane-bound enzyme differs from periplasmic hydrogenase in a number of properties: $(a) R_{F}$ values are 0.12 and 0.45 for membrane-bound and periplasmic hydrogenase respectively, $(b)$ membrane-bound hydrogenase does not cross react with antisera raised against periplasmic hydrogenase but it is digested by pancreatin, and (c) the membrane-bound enzyme is not inhibited by CO (Gow et al., 1986). Evidence for two hydrogenases, one a CO-sensitive enzyme and the other $\mathrm{CO}$-stimulated, has also been reported in D. vulgaris (Madison) by Lupton et al. (1984). Although we have found evidence for a second hydrogenase, we still do not know the physiological role of this enzyme. The highest activity of the membrane-bound enzyme was found in the cells grown on lactate under $\mathrm{N}_{2} / \mathrm{CO}_{2}$.

In lactate-limited growth conditions under $\mathrm{N}_{2} / \mathrm{CO}_{2}$, lactate was oxidized to acetate and no further oxidation of acetate occurred. It is well established that $D$. vulgaris lacks a complete tricarboxylic acid cycle (Lewis \& Miller, 1977). However, under a $\mathrm{H}_{2} / \mathrm{CO}_{2}$ gas phase, biphasic growth occurred. Firstly lactate was oxidized, followed by acetate utilization for the anabolic pathways (Badziong et al., 1978), using $\mathrm{H}_{2}$ as sole energy source. In lactate-limited conditions $\mathrm{H}_{2}$ did not provide any supplementary energy, as was evident from the lactate/acetate ratio. Similar results were obtained by Khosrovi et al. (1971); as yet we are unable to explain the above observation physiologically. Another important point which must be mentioned here is that Khosrovi \& Miller (1975) reported specific growth yields of 9.2 and $25.8 \mathrm{~g}$ (mol lactate) ${ }^{-1}$ for $D$. vulgaris under $\mathrm{Ar} / \mathrm{CO}_{2}(95: 5, \mathrm{v} / \mathrm{v})$ and $\mathrm{H}_{2} / \mathrm{CO}_{2}(95: 5, \mathrm{v} / \mathrm{v})$ respectively. However, the yields reported in the present paper are much lower and $\mathrm{H}_{2}$ increased the yield by only $47 \%$. The apparent $180 \%$ increase in yield reported by Khosrovi \& Miller (1975) might be explained on the basis that the culture was in fact capable of biphasic growth under $\mathrm{H}_{2} / \mathrm{CO}_{2}$, growing on lactate first then switching to a second phase of growth on acetate. 
In this study we have shown that if D. vulgaris is given a choice between lactate and acetate it will preferentially utilize lactate irrespective of the presence or absence of $\mathrm{H}_{2}$. Also the capacity of $D$. vulgaris to grow biphasically on lactate and acetate may have a significant ecological implication.

We wish to thank the Science and Engineering Research Council and British Petroleum plc for their financial support of this project.

\section{REFERENCES}

Badziong, W., Thauer, R. K. \& Zeikus, J. G. (1978). lsolation and characterization of Desulfovibrio growing on hydrogen plus sulphate as the sole energy source. Archives of Microbiology 116, 41-49.

Brandis, A. \& THauer, R. K. (1981). Growth of Desulfovibrio species on hydrogen and sulphate as sole energy source. Journal of General Microbiology 126, 249-252.

Christensen, D. (1984). Determination of substrate oxidised by sulphate reduction in intact cores of marine sediments. Limnology and Oceanography 29, 189-192.

CyPIONKA, H. \& PfEnNig, N. (1986). Growth yields of Desulfotomaculum orientis with hydrogen in chemostat culture. Archives of Microbiology 143, 396-399.

Gow, L. A., Pankhania, I. P., Ballantine, S. P., BOXER, D. H. \& HAMILTON, W. A. (1986). Identification of a membrane-bound hydrogenase of Desulfovibrio vulgaris (Hildenborough). Biochimica et biophysica acta 851, 57-66.

Hamilton, W. A. (1982). Lactate dehydrogenase in Desulfovibrio vulgaris. In Physiology, Ecology and Taxonomy of Sulphate-reducing Bacteria. Proceedings of FEMS Symposium, Freiburg, FRG.

Hamilton, W. A. (1985). Sulphate-reducing bacteria and anaerobic corrosion. Annual Review of Microbiology 39, 195-217.

Hatchikian, E. C., Chaigneau, M. \& LeGall, J. (1976). Analysis of gas production by growing cultures of three species of sulphate-reducing bacteria. In Microbial Production and Utilization of Gases, pp. 109-118. Edited by H. G. Schlegel, G. Gottschalk \& N. Pfennig. Göttingen: Erich Goltze.

JøRGENSEN, B. B. (1982). Ecology of the bacteria of the sulphur cycle with special reference to anoxic-oxic interface environments. Philosophical Transactions of the Royal Society B298, 543-561.

KhosRovi, B. \& Miller, J. D. A. (1975). A comparison of the growth of Desulfovibrio vulgaris under a hydrogen and under an inert atmosphere. Plant and Soil 43, 171-187.

Khosrovi, B., Macpherson, R. \& Miller, J. D. A. (1971). Some observations on growth and hydrogen uptake by Desulfovibrio vulgaris. Archives of Microbiology 80, 324-337.

Klemps, R., CyPIONKa, H., Widdel, F. \& PfenNIG, N. (1985). Growth with hydrogen, and further physiological characteristics of Desulfotomaculum species. Archives of Microbiology 143, 203-208.

Lewis, A. J. \& Miller, J. D. A. (1977). The tricarboxylic acid pathway in Desulfovibrio. Canadian Journal of Microbiology 23, 916-921.

Lupton, F. S., Conrad, R. \& Zeikus, J. G. (1984). Physiological function of hydrogen metabolism during growth of sulfidogenic bacteria on organic substrates. Journal of Bacteriology 159, 843-849.

NETHE-J AENCHEN, R. \& THAUER, R. K. (1984). Growth yields and saturation constant of Desulfovibrio vulgaris in chemostat culture. Archives of Microbiology 137, 236-240.

OdOM, J. M. \& PeCK, H. D., JR (1981). Hydrogen cycling as a general mechanism for energy coupling in the sulphate-reducing bacterium, Desulfovibrio sp. FEMS Microbiology Letters 12, 47-50.

ODOM, J. M. \& PECK, H. D., JR (1984). Hydrogenase, electron-transfer proteins, and energy coupling in the sulphate-reducing bacterium Desulfovibrio. Annual Review of Microbiology 38, 551-592.

Pankhania, I. P., Gow, L. A. \& Hamilton, W. A. $(1986 a)$. Extraction of periplasmic hydrogenase from Desulfovibrio vulgaris (Hildenborough). FEMS Microbiology Letters 35, 1-4.

Pankhania, I. P., Moosavi, A. N. \& Hamilton, W. A. $(1986 b)$. Utilization of cathodic hydrogen by Desulfovibrio vulgaris (Hildenborough). Journal of General Microbiology 132, 3357-3365.

PeCK, H. D., JR \& LeGall, J. (1982). Biochemistry of dissimilatory sulphate reduction. Philosophical Transactions of the Royal Society B298, 443-466.

Pfennig, N. \& Widdel, F. (1982). The bacteria of the sulphur cycle. Philosophical Transactions of the Royal Society B298, 433-441.

PfenNig, N., Widdel, F. \& TRÜPer, H. G. (1981). The dissimilatory sulphate-reducing bacteria. In The Prokaryotes, vol. 1, pp. 926-940. Edited by M. P. Starr, H. Stolp, H. G. Trüper, A. Balows \& H. G. Schlegel. Berlin \& Heidelberg: Springer-Verlag.

Postgate, J. R. (1984). The Sulphate-reducing Bacteria, 2nd edn. Cambridge: Cambridge University Press. Sørensen, J., Christensen, D. \& Jørgensen, B. B. (1981). Volatile fatty acids and hydrogen as substrates for sulphate-reducing bacteria in anaerobic marine sediment. Applied and Environmental Microbiology 42, 5-11.

Taras, M. J., Greenburg, A. E., Hoak, R. D. \& RaND, M. C. (1971). Sulfate. In Standard Methods for the Examination of Water and Wastewater, 13th edn, pp. 330-336. Washington, DC: American Public Health Association.

Thauer, R. K. \& MorRis, J. G. (1984). Metabolism of chemotropic anaerobes: old views and new aspects. Symposia of the Society for General Microbiology 36 (pt II), 123-168.

Traore, A. S., Hatchikian, C. E., Belaich, J.-P. \& LEGALL, J. (1981). Microcalorimetric studies of the growth of sulphate-reducing bacteria: energetics of Desulfovibrio vulgaris growth. Journal of Bacteriology 145, 191-192. 
TsujI, K. \& YAGI, T. (1980). Significance of hydrogen burst from growing cultures of Desulfovibrio vulgaris Miyazaki and the role of hydrogenase and cytochrome $c_{3}$ in energy production system. Archives of Microbiology 125, 35-42.
WIDDEL, F. (1980). Anaerober Abbau von Fettsäuren und Benzoesäure durch neu isolierte Arten Sulfat-reduzierender Bakterien. PhD thesis, University of Göttingen. 